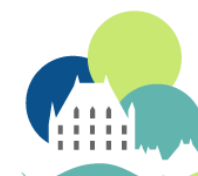

ISCAR 2017

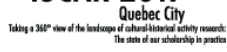

\title{
Translating Cultural-Historical Psychology: Comments from Lay Professional
}

\author{
Olga D. Tuchina \\ Peoples' Friendship \\ University of Russia \\ Moscow, Russia
}

\begin{abstract}
In translating texts for the Chess Overall Development Project (Zaretskii, 2016), we have encountered several types of challenges that may be illustrative of what translators in the field of cultural-historical psychology (CHP) may deal with. Translators use various tools and strategies in their search for equivalence. Lack of the uniform CHP vocabulary and consensus on the CHP terms: differences in transformational techniques and levels of the translators' linguistic competence and their competence in CHP as such, result in co-existence of various translations of the same concepts, which may interfere with the process of communication and become a subject of controversy. Other challenges relate to specific linguistic features of the psychological scientific discourse of CHP, i.e. the need to observe rigorous scientific requirements to style and content, and abundance in expressive, emotionally and culturally charged utterances and vocabulary. The CHP terminology is characterized by specific word formation; lack of stylistic neutrality and lack of equivalent terms in target languages. Therefore, an appropriate translation implies using a special modification technology to create a target-language term which would have an equivalent denotative meaning; meet the requirements of the scientific style and preserve its stylistic uniqueness, emotional, and cognitive relevance (ensuring congruence of the reader's experience with the author's experience as mirrored by the lexical unit).
\end{abstract}

Keywords : Cultural-historical psychology; Translation; Psychological discourse; Terminology; Connotation; Scientific style. 
Travelling of the cultural-historical thought around the world opens the door of opportunity for its adherents to share their experience of the practical application of the Vygotskian ideas and to enrich corresponding theoretical and experimental research. Hence, specialists in cultural-historical psychology (CHP) face new challenges that concern the issues of translating CHP literature, first and foremost, into English as the language of scientific communication.

In translating texts for the Chess Overall Development Project (Zaretskii, 2016), we have experienced a number of challenges that may be illustrative of what other translators of the CHP literature may have to address. Overcoming linguistic challenges is a translator's routine job and there is abundant literature on this subject. So, it may seem to have nothing to do with psychology as such. Nevertheless, oftentimes psychological tests are translated by people who have no linguistic education (PhD students, researchers, etc.), and few professional translators may enjoy working in close cooperation with professional editors (proficient both in the language issues and the subject matter of the text). Being an experienced translator of psychological texts and a practicing counselor, the author is nonetheless a novice in CHP. Therefore, this article aims to investigate challenges that may arise in the course of translating CHP works, and to propose ways to overcome these challenges to assist prospective "lay" translators (both English-speaking CHP researchers and "psychologically-illiterate" translators).

\section{Types of challenges}

Translating CHP texts implies dealing with three main groups of challenges: (1) extralinguistic or contextual (relating to translators' overall expertise in CHP and an existing consensus on understanding CHP and its terminology); (2) linguistic (relating to the language use); (3) meta-factors (relating to translators' personality and discourse).

Extralinguistic challenges relate to the environment and the context of translating and include such issues as insufficient competence in CHP (lack of information and awareness of the basic concepts and processes); lack of professional literature on translating psychological texts; lack of consensus on translating CHP terminology (first and foremost, within the community of CHP specialists); poor networking in the translators' and psychologists' communities of practice etc. These issues result in tremendous differences in translating the Vygotskian terminology and discrepancies in understanding terms and concepts (see Table 4).

The aforementioned lack of consensus is evidenced by the scarcity of reference materials on the subject. Psychological dictionaries often include chapters on $\mathrm{CHP}$, but CHP has few dictionaries of its own. Moreover, translators may want to avoid using existing translations of works by Vygotsky and his disciples as reference for creating new English translations. This limitation results from a possible unreliability of the translations which may serve as potential sources of error and distortion (Van der Veer \& Yasnitsky, 2011). For instance, Van der Veer and Yasnitsky (2011) singled out such subcategories of errors 
as inaccuracies, by which they mean "changes of the original texts that were unintended or intended with the idea of "clarifying" Vygotsky's' ideas or making him more palatable to contemporary taste" (p. 479); suppression of terms or passages; suppression of names; unidentified or suppressed citations; insertions (with the latter four types of errors resulting from censorship or falsification). Veresov (2004) points at another essential contextual challenge which has roots in readers' and translators' misunderstanding of the language of Vygotsky's scientific writings. This misunderstanding leads to inaccurate interpretation and misrepresentation of his concepts in other languages. Veresov (2004) gives a fascinating example of how the term "category" was omitted from the definition of the general genetic law of cultural development in "Mind in Society" (Vygotsky, 1978).

In this sense, the first group of challenges is close to the group of meta-factors, which include effects of translators' personality and a cultural context on the process and "the product" of translation. Broadly speaking, meta-factors are characteristics of a discourse that the translator is working with and a discourse that the translator is creating and lives in. The term "discourse" emphasizes dynamic and evolving character of the use of language which can hardly be conceptualized without accounting for a multitude of environmental, cultural and personality factors. Therefore, some researchers view discourse as "utterances", that is, "units of linguistic production (whether spoken or written) which are inherently contextualized" (Schiffrin, 1998, p. 41). Texts emerge as a result of this linguistic production and hence reflect the characteristics of its process and various contexts that language is evolving within. In pragmatic terms, translating a text my never be reduced to translating words and sentences (the linguistic content of translation) but inevitably ends in translating contexts, which are "a world filled with people producing utterances: people who have social, cultural, and personal identities, knowledge, beliefs, goals and wants, and who interact with one another in various socially and culturally defined situations" (Schiffrin, 1998, p. 363).

When translating texts in $\mathrm{CHP}$, most often we are dealing both with psychological discourse as such and a specific discourse of CHP. Moreover, the CHP discourse is multi-layer rather than homogenous, with the most obvious (but hardly the simplest) example of this being differences in the psychological discourse of Vygotsky's life time, CHP discourse in the Soviet Union and contemporary scientific psychological discourse which some investigators pointed at (Van der Veer \& Yasnitsky, 2011).

Linguistic challenges include everything that may exist under the linguistic sun from understanding phonemes and morphemes to being aware of specific features of a corresponding discourse. When translating CHP texts, we have encountered the following major linguistic challenges: (1) relating to translating psychological scientific discourse in general; (2) pertaining to specific aspects of CHP as a subject of translation; (3) linguistic challenges proper. 


\section{Coping with Linguistic Challenges}

\subsection{Psychological scientific discourse}

The space of the paper hardly allows for dwelling into details about psychological discourse. Thus, we are focusing on its most relevant and challenging aspects that are more characteristic of the linguistic content than discursive context, and hence become the epicenter of the translator's efforts.

These aspects relate to a certain ambivalence of the psychological scientific discourse which is created by the speaker's need to observe rigorous scientific requirements to style and content, and abundance in expressive, emotionally charged utterances and vocabulary. Investing efforts in staying within the boundaries of scientific discourse (implying coherent and cohesive structures, informativity, clarity and certain transparency of the text), the translator of $\mathrm{CHP}$ texts has to deal with an extensive use of imagery, comparisons, metaphors, allusions, rhetoric questions, parallelisms, repetitions etc. This "intrusion" of imagery and expressiveness is by no means accidental. Psychological discourse is always about people and for people, deep, different and expressive as they are. Psychological theory both determines practice and is determined by it. Psychologists' work with their clients gives birth to healing relationship, deep emotions and powerful insights that are experienced both by clients and psychologists. These experiences find their way to paper and transform into descriptive and explanatory means, using which psychologists conceptualize their work. It may be due to this reason why Graumann 1996, p. 90 (1996, p. 90) mentions that it is difficult to distinguish between "folk" and professional psychology as their vocabularies tend to coincide. Overall humanization of psychology which views the client as an active agent of change and research and as a partner (rather than a patient or a subject) may also contribute to fading of the boundaries between professional and folk vocabulary. The psychological language is becoming less frightening and stigmatizing; clients are being freed from labels of diagnoses and are seen as entering therapeutic relationship rather than treatment.

Imagery may also serve another purpose, namely, personality development of psychologists. It implies development of their professional competence in terms of empathic abilities and abilities relating to mentalization (Bateman \& Fonagy, 2010), when the addressee not only perceives and analyzes the conceptual material, but builds his/her own empathic and psychological picture of what is happening in the text.

The language of contemporary psychological literature is respectful, friendly, full of humor, clear, and elegantly structured. Therefore, the translator needs to account for this scientific/folk dichotomy, paying close attention to rendering both denotative (literal meaning) and connotative (cultural or emotional associations inherent in a unit of language) aspects of the text. Connotations play a decisive role in understanding, for instance, descriptions of the psychotherapeutic process in case studies. 


\subsection{Linguistic challenges proper}

Most linguistic challenges proper relate to working with CHP terminology, i.e. words or phrases that denote concepts of special fields of knowledge or practice. Extreme informativity (a term is a most precise, condensed and succinct definition of a concept) and dependence on the extralinguistic macro-context (i.e. what terms mean in their discipline) and linguistic (what they mean in an utterance) are two main aspects that make terms different from other words, although any word is a potential term. Cabré (2010, p. 359) believes that terminological challenges that translators may face, usually "relate to term understanding and the term pragmatic properties in the original text, or to the search for equivalents". Translators address and solve these challenges using reference materials (dictionaries), consulting experts and familiarizing themselves with the subject of translation to help themselves understand the context.

The vocabulary that $\mathrm{CHP}$ uses forms a specific terminological system within which terms (1) have a precise meaning and are understood by all specialists; (2) denote specific concepts; (3) have clear definitions that find their way to dictionaries. So, psychological terminology may seem to differ little from other terminological systems. The problems arise when translators encounter specific features of psychological terms depending on "peculiarities" of psychological discourse. Psychological terms are often derived from neutral-style or even colloquial (folk) words or words actively used by non-psychologists educators, neuroscientists, linguists. They may have multiple meanings and carry distinct expressive or culture-specific connotations. In case of $\mathrm{CHP}$, these connotations may even relate to the reality of the beginning of the 20th century and can hardly be understood correctly without understanding the context that they were coined in (e.g. psychopathy, defective children etc.). Thus, the appropriate translation of CHP terminology would imply understanding a term's specificity, and, hence, analyzing it from the perspectives of word formation; lexical meaning (denotation and connotation), and searching for its equivalents in the target language. These procedures represent three main issues to be addressed when translating CHP terms:

- Specific terminological word formation (ensuring equivalence at the level of morphemes).

- Lack of stylistic neutrality (ensuring equivalence at the level of connotation).

- Lack of equivalent terms in the source language (avoiding distortion of denotation when translating).

As far as terminological word formation is concerned, a successful translator needs to have knowledge of the main types of morphological derivation (including knowledge of Greek and Latin affixes), compounding (composing new words using several stems), conversion (creating one word from another by changing its class, e.g. adjectives to nouns). Understanding the word's structure and genesis may be very useful in decoding the term's meaning and rendering it in the target language (Table 1). 
Table 1

Specific Morphemes in CHP Terms

\begin{tabular}{|c|c|c|c|c|}
\hline Type & Affix & $\begin{array}{l}\text { Origin } \\
\text { and meaning }\end{array}$ & Examples & Comments \\
\hline \multirow[t]{4}{*}{ Prefix } & $\begin{array}{l}\text { inter- } \\
\text { intra- }\end{array}$ & $\begin{array}{l}\text { Latin. Between } \\
\text { Latin. Inside }\end{array}$ & $\begin{array}{l}\text { Inter-psychological } \\
\text { Intra-psychological }\end{array}$ & $\begin{array}{l}\text { Confusing "inter" and "intra" } \\
\text { is a typical translator's mistake } \\
\text { resulting in the distortion of } \\
\text { meaning }\end{array}$ \\
\hline & pere- & $\begin{array}{l}\text { Russian. } \\
\text { Multiple mean- } \\
\text { ings, including: } \\
\text { (1) repeating ac- } \\
\text { tion; }\end{array}$ & $\begin{array}{l}\text { Pere-zhivanie } \\
\text { (ex-perienc-ing) }\end{array}$ & $\begin{array}{l}\text { Denotation carried by the prefix } \\
\text { [pere-] is partly lost in transla- } \\
\text { tion (ex- has a different denota- } \\
\text { tive meaning) }\end{array}$ \\
\hline & & $\begin{array}{l}\text { (2) moving in } \\
\text { space from one } \\
\text { point to another } \\
\text { etc. }\end{array}$ & $\begin{array}{l}\text { Pere-nos [umenij] } \\
\text { (translating [skills]) }\end{array}$ & $\begin{array}{l}\text { Translations "transfer" or "trans- } \\
\text { ference" may be confused with } \\
\text { the psychoanalytic concept of } \\
\text { "transference", although it rep- } \\
\text { resents the morphological struc- } \\
\text { ture of the word pere(trans)- } \\
\text { nos(fer) more accurately. }\end{array}$ \\
\hline & so- & $\begin{array}{l}\text { Russian.Together, } \\
\text { co- }\end{array}$ & so-trudnik (co-worker) & $\begin{array}{l}\text { In modern Russian, the word } \\
\text { "sotrudnik" usually means "an } \\
\text { employee", so its terminological } \\
\text { use as "the child's partner in } \\
\text { some joint activity" may be con- } \\
\text { fusing if you ignore the morpho- } \\
\text { logical structure. The transla- } \\
\text { tion "co-worker" may be useful to } \\
\text { avoid an expressed negative con- } \\
\text { notation of "collaborator". }\end{array}$ \\
\hline Root & psych- & $\begin{array}{l}\text { Greek. psyche } \\
\text { - soul, mind, } \\
\text { spirit }\end{array}$ & $\begin{array}{l}\text { Vysshie psikh-icheskie } \\
\text { funktsii (higher men- } \\
\text { tal functions); psychol- } \\
\text { ogy; psychopathy }\end{array}$ & $\begin{array}{l}\text { Translation of "mental functions" } \\
\text { is most widely spread; however, } \\
\text { the term may also be translated as } \\
\text { "higher psychological functions" } \\
\text { reflecting the original form of the } \\
\text { term as it was proposed by Vy- } \\
\text { gotsky (Yasnitsky, 2012). }\end{array}$ \\
\hline Suffix & $-\mathrm{ik}$ & Russian. -ik & $\begin{array}{l}\text { Psikh-ik-a } \\
\text { (psyche or mind) }\end{array}$ & $\begin{array}{l}\text { Translating this term as "psy- } \\
\text { chic" (human psychic) results in } \\
\text { a gross distortion of meaning (a } \\
\text { psychic is a person having a su- } \\
\text { pernatural power of telling the } \\
\text { future). }\end{array}$ \\
\hline
\end{tabular}

Note: the list of morphemes and examples is far from being exhaustive. Our aim is to draw the reader's attention to importance of morphological analysis.

Lack of stylistic neutrality is an amazing quality of psychological terms. Connotation renders socio-cultural and personal associations of the term and operates at the level of the 
signified (Chandler, 2002, p. 120). Prokhorova (1996) believes that connotative meanings increase a term's chances to be memorized and stored within a terminological system, and specify additional qualities of a concept. She considers a term's connotative meaning as comprising emotive, expressive and figurative aspects (Table 2).

Connotations may bring about an effect of "a neutral-style word" when translators fail to identify a lexical unit as a term, which results in the distortion of the term's denotative meaning and inaccuracies in rendering some utterances. (See the example of "category" in Veresov (2004)).

One of the main characteristics of a term is its precise meaning within its field of knowledge. In practice, only a few terms meet this requirement (Table 3).

Translating terms with multiple meanings implies careful consideration of a linguistic micro-context. Terms that lack equivalents in the target language, pose another serious challenge. Usually, the non-equivalent vocabulary includes culture-specific words, proper names (especially, little-known ones), neologisms, specific concepts and terms for them which have no international equivalents (e.g. Pedagogika sotrudnichestva - the pedagogy of cooperation; subjektnaja positsiya - sense of agency; subjektnost' - agency etc.)

Lack of consensus on the CHP terminology translation results in the absence of the conceptual base of CHP in the target languages that would be shared by most specialists. Therefore, we often see a co-existence of parallel translations standing for the same concept. This creates obstacles for interpersonal communication and appropriate understanding of theoretical and research works when they are translated (Table 4).

The aforementioned differences in translation may also be due to the use of different translation techniques by different translators. We are aware that the readers of our article may be unprofessional translators, therefore we find it helpful to introduce them to some translation techniques which they can use both for understanding English translations of Russian texts and translating texts by themselves (Table 5).

All these terminology-related challenges complicate the process of decoding terms' meanings (and correspondingly, meaning of a related utterance) and encoding them in the target language. Our experience shows that appropriate translation of terms may be achieved by using a special modification technology. This technology includes both minding the context of the source-language term use, and creating a target-language term which would meet the following criteria of appropriate translation:

- has an equivalent denotative meaning;

- meets the requirements of the scientific style;

- preserves the stylistic uniqueness, emotional and cognitive relevance of a psychological term (ensuring congruence of the reader's experience with the author's experience as mirrored by the lexical unit), i.e. the translator invests efforts in rendering cultural 
Table 2

CHP Terms' Connotations

\begin{tabular}{|c|c|c|c|}
\hline $\begin{array}{l}\text { Connota- } \\
\text { tion type }\end{array}$ & $\begin{array}{l}\text { Term (preferred } \\
\text { translation) }\end{array}$ & Other translations & Comments \\
\hline \multirow[t]{4}{*}{ Figurative } & $\begin{array}{l}\text { Problem's epi- } \\
\text { center, problem } \\
\text { epicentre (prob- } \\
\text { lemny epicenter) }\end{array}$ & $\begin{array}{l}\text { "Epicenter of a chal- } \\
\text { lenge problem", } \\
\text { "problem point", } \\
\text { "point of perplexity" }\end{array}$ & $\begin{array}{l}\text { These translations lead to a slight distortion of de- } \\
\text { notative meaning and loss of imagery. }\end{array}$ \\
\hline & $\begin{array}{l}\text { Vnutrenniy/ } \\
\text { vneshniy plan } \\
\text { deistvii (internal } \\
\text { /external or in- } \\
\text { terior/exterior } \\
\text { plane of action); }\end{array}$ & $\begin{array}{l}\text { Internal /external } \\
\text { plan... }\end{array}$ & $\begin{array}{l}\text { The Russian term "plan" may be translated both as } \\
\text { "plane" and "plan". Misunderstanding of the im- } \\
\text { age of "a plane" leads to distortion of the denotative } \\
\text { meaning. }\end{array}$ \\
\hline & Orudije (tool) & Means & $\begin{array}{l}\text { Translating the term "orudije" as "means of action" } \\
\text { may render the denotative meaning but deprives } \\
\text { the term of its implicit meaning and associations } \\
\text { with cultural tools }\end{array}$ \\
\hline & $\begin{array}{l}\text { Vector razvitiya } \\
\text { (dimension of } \\
\text { development) } \\
\text { Mnogovektornaya } \\
\text { model (multidi- } \\
\text { mensional model) }\end{array}$ & $\begin{array}{l}\text { Vector of develop- } \\
\text { ment } \\
\text { Multivector model }\end{array}$ & $\begin{array}{l}\text { In our translation, we replace the image of "vector" } \\
\text { with the image of "a dimension" which leads to the } \\
\text { loss of initial imagery and part of the denotative } \\
\text { meaning (directionality of development), but ren- } \\
\text { ders the denotative meaning of a space where devel- } \\
\text { opment occurs and the abilities enjoy improvement. }\end{array}$ \\
\hline $\begin{array}{l}\text { Emotive } \\
\text { Nega- } \\
\text { tive }\end{array}$ & $\begin{array}{l}\text { Trudnost' } \\
\text { (challenge) }\end{array}$ & Difficulty & $\begin{array}{l}\text { These words may be used interchangeably but we } \\
\text { prefer using "challenge" as it both conveys a neg- } \\
\text { ative connotation of something which is hard to } \\
\text { achieve and a positive meaning of something which } \\
\text { may be addressed and overcome }\end{array}$ \\
\hline $\begin{array}{l}\text { Emotive } \\
\text { Positive }\end{array}$ & $\begin{array}{l}\text { Samostoyatelny } \\
\text { (Autonomous) }\end{array}$ & Independent & $\begin{array}{l}\text { Autonomous is preferred as it renders positive } \\
\text { connotation but the context should be taken into } \\
\text { consideration. }\end{array}$ \\
\hline Expressive & Opora (Support) & $\begin{array}{l}\text { Scaffolding, material } \\
\text { tools, aids or support- } \\
\text { ive materials }\end{array}$ & $\begin{array}{l}\text { Translations may be used interchangeably depend- } \\
\text { ing on the microcontext }\end{array}$ \\
\hline Cultural & $\begin{array}{l}\text { Psikhopatiya } \\
\text { (Psychopathy) }\end{array}$ & $\begin{array}{l}\text { Antisocial Personal- } \\
\text { ity Disorder, Person- } \\
\text { ality Disorder }\end{array}$ & $\begin{array}{l}\text { Carries both emotive negative and cultural conno- } \\
\text { tations. } \\
\text { What is now considered a derogatory term used } \\
\text { to be a diagnostic category widely-used in the So- } \\
\text { viet Union and Russia throughout the 20th century } \\
\text { (even now by "old-school" psychiatrists). Extended } \\
\text { terminological translations aiming at improving the } \\
\text { style and making the text sound modern and com- } \\
\text { pliant with current diagnostic categories devoid } \\
\text { the text of its cultural flavor and distort mean- } \\
\text { ing, especially if this term is used by modern re- } \\
\text { searchers when describing recent situations (then it } \\
\text { may speak about the researcher's scientific frame of } \\
\text { reference) }\end{array}$ \\
\hline
\end{tabular}


Table 3

Terms with Multiple Meanings and their Possible Translations

\begin{tabular}{ll}
\hline Russian Term & Basic Translation Options \\
\hline Obuchenije & Learning, instruction, teaching, training, education \\
Vospitanije & Upbringing, education \\
Subject & Subject, Agent \\
Perezhivanije & Emotional experience, experiencing \\
Trevoga & Concern, anxiety, agitation \\
Myshlenije & Thinking, thought, cognition, reflection \\
Refleksivny & Reflective, reflexive, reflection \\
Osoznanije & Awareness, consciousness, mindfulness, mentalization \\
Razvitije & Development, improvement, progress, evolution \\
Razvivayushchijsya & Developing, improving, evolving, emerging \\
Videnije & Perception, mental image, vision, visualization, sight and seeing \\
Deyatelnost & Activity, action, practice, performance \\
Protokol & Minutes, transcript, protocol \\
\hline
\end{tabular}

Table 4

Co-existing translations of $\mathrm{CHP}$ terms

\begin{tabular}{|c|c|}
\hline Russian Term & Co-existing Translations \\
\hline $\begin{array}{l}\text { Refleksivno-deyatelnostnyi pod- } \\
\text { khod }\end{array}$ & $\begin{array}{l}\text { Reflection and Activity v. Reflexiveactive v. Reflexive and } \\
\text { activity approach }\end{array}$ \\
\hline Vnutrenniy/Vneshniy plan deistvii & Internal/external plane v. plan of action \\
\hline $\begin{array}{l}\text { Teorija poetapnogo formirovanija } \\
\text { umstvennykh dejstviy }\end{array}$ & $\begin{array}{l}\text { Theory of the stage-by-stage formation of mental actions } \\
\text { Theory of the stepwise formation of mental actions }\end{array}$ \\
\hline $\begin{array}{l}\text { Zona blizhaishego razvitija } \\
\text { Novoobrazovanie }\end{array}$ & $\begin{array}{l}\text { Zone of proximal v. potential development } \\
\text { New mental formation v. New mental acquisition v. Key } \\
\text { milestone in development }\end{array}$ \\
\hline Samoopredelenie & Self-identification v. self-determination v. self-definition \\
\hline Dolgota and shirota (of a concept) & Longitude and latitude v. length and breadth \\
\hline Sposob deistviya & Mode v. means v. methods of action \\
\hline
\end{tabular}

Note: Preferred equivalents are italicized.

and expressive connotations which the term carries to preserve the main characteristics of a given psychological scientific discourse. 
Table 5

Translating the Concept of Perezhivanie Using Various Translation Techniques

\begin{tabular}{|c|c|c|}
\hline Technique & Perezhivanie & Comment \\
\hline $\begin{array}{l}\text { Identifying an existing } \\
\text { equivalent }\end{array}$ & - & - \\
\hline $\begin{array}{l}\text { Transcription and transliter- } \\
\text { ation }\end{array}$ & Perezhivanie & $\begin{array}{l}\text { Is used when it is important both } \\
\text { to be succinct and to render speci- } \\
\text { ficity of a culture-specific item (CSI) } \\
\text { if there is no precise equivalent in a } \\
\text { target language. }\end{array}$ \\
\hline Calquing or loan translation & Experiencing or reexperiencing & $\begin{array}{l}\text { Although calquing seems to be me- } \\
\text { chanical literal translation, transla- } \\
\text { tors usually need to combine it with } \\
\text { other modification techniques. }\end{array}$ \\
\hline $\begin{array}{l}\text { Semantic modification (gen- } \\
\text { eralization or particulariza- } \\
\text { tion) }\end{array}$ & Emotional experiencing & $\begin{array}{l}\text { Here particularization or narrowing } \\
\text { of meaning is used. }\end{array}$ \\
\hline $\begin{array}{l}\text { Explication } \quad \text { (descriptive } \\
\text { translation) }\end{array}$ & $\begin{array}{l}\text { According to "hygotsky, } \\
\text { perezhivanie is "how a child } \\
\text { becomes aware of, interprets, and } \\
\text { emotionally relates to a certain } \\
\text { event" (adopted from (Veresov, } \\
\text { 2016, p. 130)) }\end{array}$ & $\begin{array}{l}\text { Is used for CSIs and is usually pre- } \\
\text { sented as a footnote or a glossary's } \\
\text { entry. The main disadvantages are } \\
\text { length and possible distortion of the } \\
\text { concept's meaning by translators. }\end{array}$ \\
\hline
\end{tabular}

\section{Conclusions}

We have shown that translators have to overcome multiple challenges when translating CHP literature. In order to accomplish the overarching goal of achieving translation equivalence of the texts, translators use various tools and strategies when searching for equivalents. Lack of the uniform terminological base and consensus on the CHP terms, differences in transformational techniques and levels of the translators' competence both in languages of translation and CHP as such, result in co-existence of various translations of the same concepts. Sometimes these translations may be interchangeable and are quite clear both to Russian and English speakers, and sometimes they are interfering with the process of communication and become a subject of controversy.

We believe that $\mathrm{CHP}$ as branch of knowledge and practice which has been constantly evolving and gaining adherents all over the world, needs to reach a consensus on its terminology, both from the historical and theoretical perspective (in terms of understanding and translating historical texts and terminology used by Vygotsky and his disciples) and from the pragmatic perspective (addressing the need to disseminate research and best practices in the field).

This could be accomplished in different ways: creating a special task force or a project for (1) exploring historical and contemporary CHP terminology; (2) creating CHP glossaries (lists of terms) in Russian, English and other languages; (3) comparing them to create 
a uniform CHP glossary; (4) creating CHP dictionaries, which would include CHP basic concepts and chapters on them written by the experts on the field; (5) creating a network or an organizational structure for translators working with CHP texts to enable their interaction and sharing knowledge and experience etc. These are just a few suggestions for overcoming extralinguistic translation difficulties to start from.

As to the discourse-related and proper linguistic challenges, there are no ready-made recipes. Translation is a process of creating and, moreover, co-creating texts in an entirety of their explicit and implicit meanings. Therefore, much depends on the translator's personality and his/her manner to cope with challenges. Nevertheless, we would like to share principles that helped us to translate a number of CHP texts and get positive feedback from readers, authors and publishers. Our main strategy in translating is taking a respectful stance towards the text and its authors, and the translation principles are a direct consequence of this strategy:

1. Translating very close to the text: investing efforts to render each word and each connotation. Interpreting is fine as long as you are the author of the text. Unless this is the case, check all interpretations with the authors. Usually, a need to interpret arises when you have some difficulty understanding the text's meaning.

2. Paying close attention to the context and taking the author's perspective so as to be able to understand what he/she wanted to communicate. "Empathizing" with the author in no way means fantasizing about his/her ideas or motives.

3. Asking questions: any questions, even those that seem minor and "stupid". A "stupid" question may be very smart, indeed. Checking meanings and utterances that you doubt or find strange or difficult to comprehend is very useful. Authors tend to answer translators' questions eagerly.

4. Keeping it simple. Although translators invest efforts to preserve the author's style in translation, they need to keep the main features of the scientific psychological discourse in mind and aim at stylistic transparency of the text. We find it useful to avoid passive voice and excessively long and complex sentences wherever possible.

5. Agreeing all the changes that are introduced to the text (including descriptive translations and translator's comments) with the author to avoid distortion of meanings. Translators' contribution should be clearly indicated in the text.

\section{References}

Bateman, A., \& Fonagy, P. (2010). Mentalization based treatment for borderline personality disorder. World psychiatry, 9(1), 11-15.

Cabré, M. T. (2010). Terminology and translation. In Y. Gambier \& L. van Doorslaer (Eds.), Handbook of translation studies (p. 356-365). Amsterdam/Philadelphia: John Benjamins Publishing Company. 
Chandler, D. (2002). Semiotics: the basics. New York: Routledge.

Graumann, C. F. (1996). Psyche and her descendants. In C. F. Graumann \& K. J. Gergen (Eds.), Historical dimensions of psychological discourse (pp. 83-102). Cambridge: Cambridge University Press.

Prokhorova, V. N. (1996). Russkaya terminologiya (leksiko-semanticheskoe obrazovanie)[Russian terminology (lexical-semantic education)]. Moscow: Filologicheskiy fakul'tet Publ.

Schiffrin, D. (1998). Approaches to discourse. Journal of Pragmatics, 3(29), 355-359.

Van der Veer, R., \& Yasnitsky, A. (2011). Vygotsky in english: What still needs to be done. Integrative Psychological and Behavioral Science, 45(4), 475-493.

Veresov, N. (2004). Zone of proximal development (ZPD): the hidden dimension? Language as Culture-Tensions in Time and Space., 1, 13-30.

Veresov, N. (2016). Perezhivanie as a phenomenon and a concept: Questions on clarification and methodological meditations. Cultural-Historical Psychology, 12(3), 129-148.

Vygotsky, L. S. (1978). Mind in society: The development of higher psychological processes. Cambridge: Harvard University press.

Yasnitsky, A. (2012). L. S. Vygotsky's "tool and sign" as a "benign forgery": Introduction to virtual dialogue. PsyAnima, Dubna Psychological Journal, 5(1), 112-113.

Zaretskii, V. K. (2016). Odin shag v obuchenii - sto shagov v razvitii: Ot idei k praktike [Vygotsky's Principle "One step in learning - One hundred steps in development": From idea to practice]. Kul'turno-istoricheskaya psikhologiya [Cultural-Historical Psychology], 12(3), 149-188. 